\title{
Implementation of Lean Six Sigma in public Road Transportation
}

\author{
Venkata Sai Mounik Yerubandi, Praveen Mathi, Kali Prasad Varma Namburi
}

\begin{abstract}
This paper presents the defect identification, defect reduction and continuous improvement in public road transportation by using lean six sigma methodologies. Lean methodologies will reduce the waste i.e. unnecessary efforts or tasks. The main aim of lean is to improve productivity i.e. to increase profit to the organization. The six sigma methodologies are centered towards the elimination of variations i.e. reduction of defects. The main objective of six sigma is 3.4 defects per million opportunities, whichlead to fulfilling the customer requirements. The six sigma tools arearithmeticaland statistical based. The lean mainly focused on the flow and the six sigma mainly focused on the problem. By combining, these two methodologies and implementing in public road transportation will leads to increase the profit of the organization and customer satisfaction. The results achieved by using DMAIC methodology and lean tools.
\end{abstract}

Index Terms:lean, six sigma, methodologies, variations, continuous improvement, DMAIC.

\section{INTRODUCTION}

There are many lean six sigma tools, but selecting the right tools plays a key role.

Some of the six sigma methodologies ${ }^{[1]}$ :

DMAIC-Define, Measure, Analyse, Improve, Control.

DMADV-Define, Measure, analyze, Design, Verify.

DFSS-Design for Six Sigma-Define, Identify, Design, Optimize, Verify.

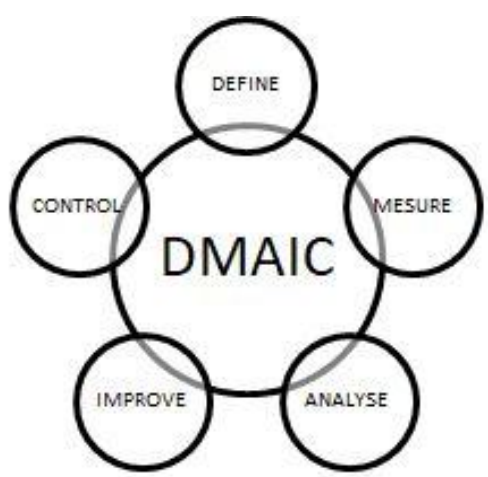

Figure 1: - DMAIC Circle

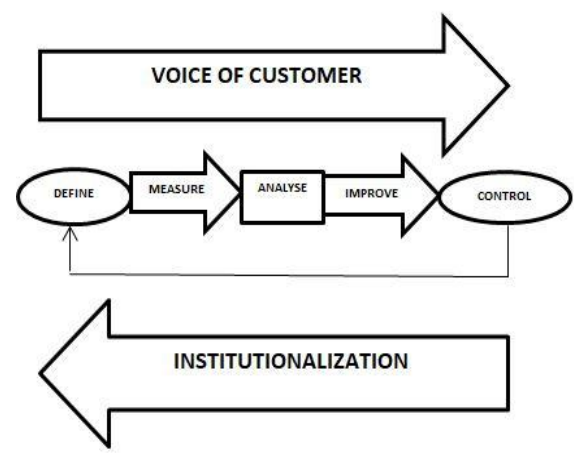

Figure 2: - the voice of the customer route map.

Niraj G. Pai Bhale ${ }^{[5]}$ aims to reduce the process variation of the chopped strand mat in a fiber industry, the author adopted DMAIC methodology to optimize the production process and to reduce the process variation, critical process parameters have been identified and used Taguchi method to identify the key factors and their levels. Jijo Antony ${ }^{[4]}$ discussed the successful implementation of six sigma in a critical and high precision manufacturing of the automotive products, The author implemented six sigma DMAIC methodology and improved the first pass yield from $80 \%$ to $99.4 \%$ and an approximate of $\$ 70000$ per annum savings was reported, in addition to this customer-facing benefits of improved quality. Salah Deeb ${ }^{[8]}$ has presented a framework for successful implementation of six sigma in small and medium scale enterprises, this is formalized by the metamodel.

Application of Lean Six Sigma in the manufacturing sector is highly successful over the decades, but the implementation in the service sector was a new and controversial topic. Alessandro laureani ${ }^{[7]}$ aims for the successful implementation of six sigma in a call center. The author finds the increase in the first call resolution ratio, reduction in operator turnover.

Benefits of LSS in manufacturing and service include ${ }^{[7]}$ :

1. Ensuring products/services meet the customer requirements.

2. Eliminating Muda (Waste).

3. Reducing the transactions / Defective products.

4. Shortening cycle / Transaction time.

5. Delivering the right product/service at the right time in the right place.

Main reasons for implementation of Lean Six Sigma in services $^{[6]}$ :

1. Service process is costly and slow.

2. Majority of the service processes are complex and having huge "WIP" which tends to increased waiting time.

Revised Manuscript Received on November 05, 2019.

Venkata Sai Mounik Yerubandi, M. Tech student, Vishnu Institute of technology, Mechanical Department, Bhimavaram, Andhra Pradesh, India.

Praveen Mathi, Assistant professor, Vishnu Institute of technology, Mechanical Department, Bhimavaram, Andhra Pradesh, India.

Kali Prasad Varma Namburi, M. Tech student, Vishnu Institute of technology, Mechanical Department, Bhimavaram, Andhra Pradesh, India.
3. By applying the Pareto principle $80 \%$ delay is caused by $20 \%$ activities, thereby improving the speed of vital $20 \%$ will 
leads to the reduction of trivial $80 \%$.

The public is the main consideration of public road transportation so, the voice of costumer plays a vital role. The voice of costumer is considered by conducting surveys, reviews, options, Etc. This was clearly explained by S.K. Bhattacharyya ${ }^{[2]}$. Then convert the customer voice to our requirement for the use of mathematical and statistical operation. H. Brian Hwarng ${ }^{[3]}$ had explained the translating customer's voice into operations requirements by applying Quality Function Development(QFD).

The implementation of lean six sigma is done by considering the previous data of the public road transport medium (buses)for a certain time period. The DMAIC is widely used methodology in the service sector. The DMAIC methodology with the assistance oflean tools will give continuous improvement and reduce the defects more efficiently. This paper ideology is to implement the lean six sigma in public road transportation to improve the service, which givesthe highest profits to the organization and gives good customer satisfaction.

\section{IMPLEMENTATION}

\section{DMAIC}

DMAIC consists of five different phases they are

1. Define Phase.

2. Measure Phase.

3. Analyse Phase.

4. Improve Phase.

5. Control Phase.

\section{DEFINE PHASE}

In this phase by considering the voice of costumer.

- The major problem is the price variation of diesel.

- Improper pricing of travel fare.

- There is no direct bus service to Eluru via Hanuman junction.

- Improper use of staff.

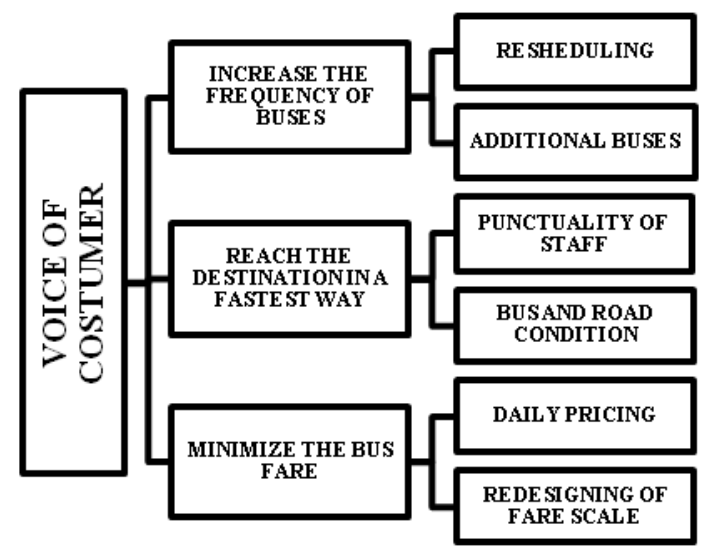

Figure 3: - critical to the quality tree.

\section{MEASURE PHASE}

\section{DATA COLLECTION}

- Route - Nuzvid to Eluru.

- 3 types of routes they are
1. Via Hanuman junction (Dwaraka Tirumala bus) $(6: 30$, 13:30) as showed in appendix-1.3.

2. Via musunuru,gopavaram $(5: 00,6: 45,10: 45,14: 45$, 17:00)as showed in appendix-1.2.

3. Via devargunta $(6: 00,9: 30,10: 30,14: 30)$ as showed in appendix-1.4.

- No of seats in the bus -55(excluding conductor).

- No of buses.

1. Via Hanuman junction -1 bus.

2. Via musunuru, gopavaram-2 buses.

3. Via devargunta- 2 buses.

- The Lap time of all three routes is 1 hour 45 minutes.

- Distance between Nuzvid and Eluru in $1 \& 2$ routes is $50 \mathrm{kms}$, route 3 is $45 \mathrm{kms}$.

- The average Mileage of bus is 5.48 kilometer per litre.

- Salary for driver Rs14000 per month i.e. (Rs467/day).

- Salary for conductor Rs13000 per month i.e.(Rs434/day).

- No of breakdowns- 1 in a month.

\section{DATA ANALYSIS}

- The distance between Nuzvid and Eluru is $50 \mathrm{~km}$.

- Average mileage $-5.48 \mathrm{kmpl}$.

- Round trip -100 kms.

- $\quad$ Diesel required $-100 / 5.48=18.25$ litres

- Total cost for diesel (round trip) $=($ diesel required $) \times($ cost of the diesel $)$ $=18.25 \times 80=$ Rs 1460 .

- Total cost of diesel per day $=($ Total cost of diesel $) \times($ Total round trips $)$ $=1460 \times 11=$ Rs16060.

- $\quad$ Salary of driver = Rs467 per day.

- $\quad$ Salary of conductor = Rs434 per day.

- $\quad$ No of buses $=5$.

- $\quad$ No of round $=11$.

- $\quad$ No seats in the bus $=55$

- Total salaries per day $=($ sum of salary of driver and conductor $) \times($ no of buses) $=(467+434) \times(5)$ $=$ Rs4505.

- $\quad$ No of tickets per one round trip $=110$.

- Maximum no of passengers served per day $=1210$.

- $\quad$ The average bus fare =Rs30.

- Total turnover per day $=$ (maximum no of costumers $) \times$ (average bus fare)

- $\quad=1210 \times 30=\operatorname{Rs} 36300$.

- $\quad$ Maintenance cost per bus = Rs250 per day

- Maintenance cost per 5 buses = Rs1250 per day

- Total income per day $=$ (total turnover per day) $-[$ (total cost of diesel) + 
(total maintenance cost) + (total salaries)

$=(36300)-[(16060)+(1250)+(4505)]$

$=$ Rs14485

- $\quad$ Let price of bus be Rs1400000

- $\quad$ Cost of 5 buses $=5 \times 1400000$ $=$ Rs7000000

- Break even comes at 484 days

- Break even

$=($ cost of the bus $) /$ (income per day)

$=7000000 / 14485$

$=484$ days.

If in average the occupancy rate is only 45 . Then the breakeven point comes at 888 days. Easily a bus can perform to its best more than 5 years.

Therefore, the main aim is to get optimum occupancy rate.

\section{ANALYZE PHASE}

In analyze phase the problem and its root can be analyzed in this phase with the help of different tools. However, in this Ishikawa diagram (cause and effect diagram) is used for the present study. Figure 5 shows the cause and effect diagram for the occupancy rate

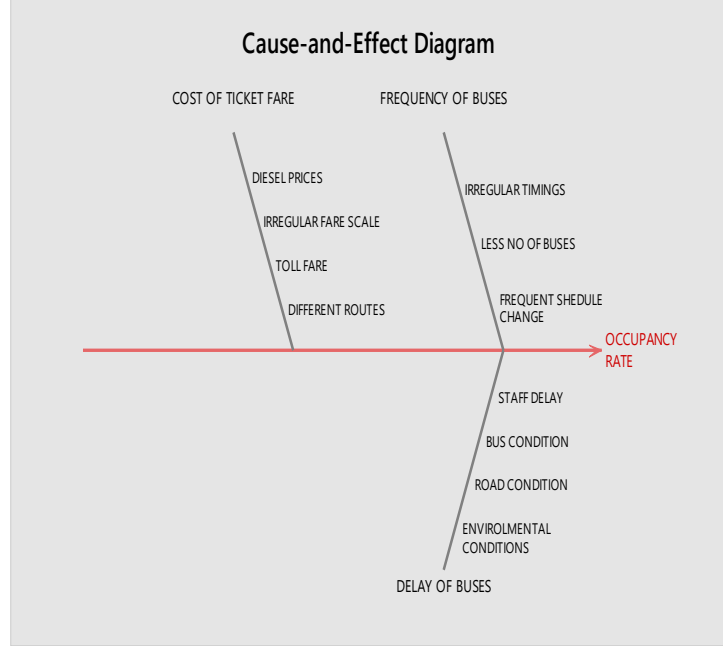

Figure 5: - cause and effect diagram.

\section{IMPROVE PHASE}

\section{PDCA (PLAN DO CHECK ACT/ADJUST)}

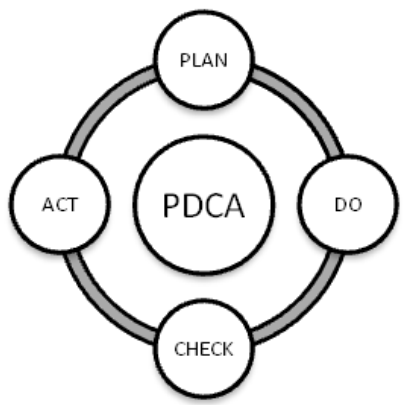

Figure 4: -PDCA.

PLAN- Identify the issue \& root causes.

Use visual management to make problem visible, the problem is less occupancy rate and irregular timings of buses. DO- Fix a problem.
Apply countermeasures to reduce root causes; if we reschedule the bus timings then the public will not seek the other mode of transportation.

CHECK-Assess if the problem is fixed.

Compare the results with goals.

ACT/ADJUST- Refine the improvement (continuous improvements).

By the end of analyze phase thethree root problems which should be solved are.

1. The frequency of buses.

2. Delay of buses.

3. Cost of the ticket

The frequency of buses can be increased by rescheduling or by adding extra buses to required routes after rescheduling if needed. By this delay of buses, the problem can also be solved to some extinct.

\section{RESCHEDULING}

Route1: - via Hanuman junction bus timings are 6:30 and 13:30 at Nuzvid. There will be no schedule changes because of extra toll charges collected at the Kalapana toll plaza. Based on the voice of the customer by addition of one bus at 7:00 can be beneficiary to students and employees.

Route2: - via musunuru, gopavaram according to voice of costumer route(farmers, daily labour and students) so there is need of buses at early morning, mid-day and late in the evenings, so best suitable times are $5: 00,6: 45$ or 7:00, 10:00, 12:45,17:00 and 18:30.

Route 3: - via devargunta is the shortest route to Eluru and less ticket fair among other two routes but it had a less occupancy rate. This route can be best used by the employees, patients to Asramam hospital and some students. So the suitable timings are 6:00, 7:30, 10:30, 1:30, and 14:30.

The delay of buses completely not possible because of environmental conditions and condition of roads. As it can be reducedby maintaining good bus condition and specific lap time, by this measures it can be reduced to a good extinct.

The cost of the ticket can be optimized by daily pricing because the cost diesel plays a vital role as the diesel also in daily pricing bases so it can be useful to both the public and the organization. Also assigning junior staff to the buses so that the staff wages can be reduced where the maintenance cost will reduce.

\section{CONTROL PHASE}

In thisphase, monitoring and response plan will be generated based on define, measure, analyze and improve phases. Appendix-1.5 shows the monitoring and respond plan for rescheduling of buses, reduce of travel time and daily pricing. By this, we will find the pit holes and respond quickly to it.

\section{CONCLUSION}

By implementing lean six sigma methodologies in public road transportationan optimum solutioncan be obtained. In this study problems likeless bus frequency, delay in buses, the price of the ticket was optimized by rescheduling, specific lap timing, daily pricing of the ticket by considering the voice of the customer. By these methodologies, customer satisfaction and profits to the organization will increase. 


\section{ACKNOWLEDGEMENT}

Sincere thanks to Shri Venu Mangam, N Naga Krishna and $\mathrm{K}$ Anupama francy for their support and guidance in this work.

\section{REFERENCES}

1. https://www.isixsigma.com/methodology/.

2. S.K. Bhattacharyya and Zillur Rahman, (2004), "Capturing the customer's voice, the centerpiece of strategy making", European Business Review, Vol. 16 Iss 2 pp. 128 - 138.

3. H. Brian Hwarng, Cynthia Teo, (2001), "Translating customer's voices into operations requirements", International Journal of Quality \&amp; Reliability Management, Vol. 18 Iss 2 pp. 195-226.

4. Jiju Antony and E. V. Gijo, and S.J. Childe, (2012) Case study in six sigma methodology: manufacturing quality improvement and guidance for managers. Production Planning and Control, 23 (8). pp. 624-640.

5. Niraj G. Pai Bhale, P.K. Srividhya, V. Mariappan, Amol N. Patil, and M. Prabhakaran, International Journal of Performability Engineering, Vol. 13, No. 1, January 2017, pp. 19-28.

6. George, M.L, Lean Six Sigma for Services, 2003

7. Alessandro Laureani and Jiju Antony, Lean six sigma in a call center: a case study, International Journal of Productivity and Performance Management, Vol. 59 No. 8, 2010 pp. 757-768

8. Salah Deeb, Hind bril-EI Haouzi, Alexis Aubry, Michele Dassisti, "A generic framework to support the implementation of six sigma approach in SMEs", IFAC PapersOnLine 51-11 (2018) 921-926.

\section{APPENDIX-1.1}

\begin{tabular}{|l|l|l|l|l|l|l|l|l|l|l|}
\hline KILOMERTERS & 5 & 10 & 15 & 20 & 25 & 30 & 35 & 40 & 45 & 50 \\
\hline $\begin{array}{l}\text { FARE IN } \\
\text { RUPEES }\end{array}$ & 5 & 10 & 10 & 15 & 15 & 20 & 25 & 25 & 30 & 30 \\
\hline
\end{tabular}

\section{APPENDIX-1.2}

\begin{tabular}{|c|c|c|}
\hline $\begin{array}{c}\text { STAGE } \\
\text { NO }\end{array}$ & STAGE NAME & FARE \\
\hline 1 & NUZVID & 0 \\
\hline 2 & POTHUREDDIPALLI & 5 \\
\hline 3 & N.S.CANEL & 10 \\
\hline 4 & MUSUNURU & 10 \\
\hline 5 & GOPAVARAM & 15 \\
\hline 6 & KOBBARITHOTA & 15 \\
\hline 7 & VELPUCHERLA & 20 \\
\hline 8 & KOPPAKA & 25 \\
\hline 9 & SANIVARRPETA & 25 \\
\hline 10 & ELURU N.B.S & 30 \\
\hline 11 & ELURU O.B.S & 30 \\
\hline
\end{tabular}

\begin{tabular}{|c|c|c|}
\hline $\begin{array}{c}\text { STAGE } \\
\text { NO }\end{array}$ & STAGE NAME & FARE \\
\hline 1 & NUZVID & 0 \\
\hline 2 & TUKKULURU & 5 \\
\hline 3 & GOLLAPALLI & 10 \\
\hline 4 & MEERJAPURAM & 10 \\
\hline 5 & SEETARAMPURAM & 15 \\
\hline 6 & H.JUNCTION & 15 \\
\hline 7 & BOMMULURU & 20 \\
\hline 8 & KALAPARRU & 25 \\
\hline 9 & VATLURU & 25 \\
\hline 10 & ELURU & 30 \\
\hline
\end{tabular}

NOTE:-Toll fare of Rs 5 collected on cros sing kalaparru toll plaza
APPENDIX-1.3

\begin{tabular}{|c|c|c|}
\hline $\begin{array}{c}\text { STAGE } \\
\text { NO }\end{array}$ & STAGE NAME & FARE \\
\hline 1 & NUZVID & 0 \\
\hline 2 & TUKKULURU & 5 \\
\hline 3 & DEVAR GUNTA & 10 \\
\hline 4 & ASRAMAM & 10 \\
\hline 5 & MADICHARLA & 15 \\
\hline 6 & BHOGAPURAM & 15 \\
\hline 7 & VATLURU & 20 \\
\hline 8 & ELURU N.B.S & 25 \\
\hline 9 & ELURU O.B.S & 25 \\
\hline
\end{tabular}

\section{APPENDIX-1.4}

\begin{tabular}{|c|c|c|c|c|c|c|c|c|}
\hline \multicolumn{6}{|c|}{ MONITORING PLAN } & \multicolumn{3}{|c|}{ RESPONSE PLAN } \\
\hline $\begin{array}{c}\text { NAVE OF THE } \\
\text { MEASLRE }\end{array}$ & $\begin{array}{c}\text { IPUT } \\
\text { OUTPUT } \\
\text { PROCESS }\end{array}$ & $\begin{array}{l}\text { WHAT } \\
\text { IS } \\
\text { TARGE } \\
\text { I? } \\
\end{array}$ & $\begin{array}{c}\text { METHOD } \\
\text { OF DATA } \\
\text { CAPTURED }\end{array}$ & $\begin{array}{l}\text { CHECKING } \\
\text { FREQLENCY }\end{array}$ & $\begin{array}{c}\text { PERSON } \\
\text { RESPONSBLL } \\
\text { E }\end{array}$ & $\begin{array}{c}\text { UPPERLOWER } \\
\text { TRIGGER } \\
\text { PONT }\end{array}$ & $\begin{array}{c}\text { WH0 } \\
\text { WILL } \\
\text { RESPOND } \\
?\end{array}$ & $\begin{array}{l}\text { REACTION } \\
\text { PLAN }\end{array}$ \\
\hline $\begin{array}{l}\text { Reschedule the } \\
\text { busses }\end{array}$ & $\begin{array}{l}\text { Voice of } \\
\text { costumer }\end{array}$ & $\begin{array}{c}\text { To get } \\
\text { highest } \\
\text { occupan } \\
\text { cy rate }\end{array}$ & Ticketing & Stage wise & Conductor & $\begin{array}{c}45 \text { seats should } \\
\text { be filled at every } \\
\text { stage }\end{array}$ & manger & $\begin{array}{l}\text { If less then } 15 \\
\text { seats are filled } \\
\text { then } \\
\text { reschededle it } \\
\text { unilit it btains } \\
\text { it goval }\end{array}$ \\
\hline $\begin{array}{l}\text { Reduce the travel } \\
\text { time }\end{array}$ & $\begin{array}{c}\begin{array}{c}\text { Personal } \\
\text { observatio } \\
\text { n }\end{array} \\
\text { nat }\end{array}$ & $\begin{array}{c}\text { To } \\
\text { attract } \\
\text { the } \\
\text { public }\end{array}$ & $\begin{array}{c}\text { Lap timing } \\
\text { derominatio } \\
\text { nateach } \\
\text { stage }\end{array}$ & $\begin{array}{l}\text { At erery stage } \\
\text { stat }\end{array}$ & $\begin{array}{l}\text { Driver or } \\
\text { conductor }\end{array}$ & $\begin{array}{l}\text { Total travel ime } \\
\text { to destiny should } \\
\text { be l hour } 30 \\
\text { minutes }\end{array}$ & driver & $\begin{array}{l}\text { Find the root } \\
\text { cause and } \\
\text { reetify it }\end{array}$ \\
\hline Daily pricing & $\begin{array}{c}\text { Diesel } \\
\text { daily } \\
\text { pricing }\end{array}$ & $\begin{array}{c}\text { Optimu } \\
\text { m ticlet } \\
\text { price }\end{array}$ & $\begin{array}{l}\text { Cost of diesel } \\
\text { and reduce } \\
\text { the } \\
\text { maintains } \\
\text { cost }\end{array}$ & daily & $\begin{array}{c}\begin{array}{c}\text { Traffic control } \\
\text { in charge }\end{array} \\
\end{array}$ & 25 to 35 & $\begin{array}{c}\text { Traffit } \\
\text { control in } \\
\text { charget }\end{array}$ & $\begin{array}{l}\text { If daily pricing } \\
\text { is not possible } \\
\text { then change to } \\
\text { monthly twice }\end{array}$ \\
\hline
\end{tabular}

